\title{
Tyrosine kinase inhibitors reprogramming immunity in renal cell carcinoma: rethinking cancer immunotherapy
}

\author{
L. M. A. Aparicio ${ }^{1}$ I. P. Fernandez ${ }^{2}$ J. Cassinello ${ }^{3}$
}

Received: 24 January 2017 / Accepted: 25 March 2017/Published online: 13 April 2017

(C) The Author(s) 2017. This article is an open access publication

\begin{abstract}
The immune system regulates angiogenesis in cancer by way of both pro- and antiangiogenic activities. A bidirectional link between angiogenesis and the immune system has been clearly demonstrated. Most antiangiogenic molecules do not inhibit only VEGF signaling pathways but also other pathways which may affect immune system. Understanding of the role of these pathways in the regulation of immunosuppressive mechanisms by way of specific inhibitors is growing. Renal cell carcinoma (RCC) is an immunogenic tumor in which angiogenesis and immunosuppression work hand in hand, and its growth is associated with impaired antitumor immunity. Given the antitumor activity of selected TKIs in metastatic RCC (mRCC), it seems relevant to assess their effect on the immune system. The confirmation that TKIs improve cell cytokine response in mRCC provides a basis for the rational combination and sequential treatment of TKIs and immunotherapy.
\end{abstract}

Keywords Tyrosine kinase inhibitors .

Immunomodulation · Angiogenesis · Renal cell carcinoma · Immunotherapy

L. M. A. Aparicio

luis.anton.aparicio@sergas.es

1 Medical Oncology Department, Hospital Universitario A Coruña, Xubias s/n, 15615 La Coruña, Spain

2 Medical Oncology Department, Hospital Universitario de Cabueñes, Gijón, Spain

3 Medical Oncology Department, Hospital Universitario de Guadalajara, Guadalajara, Spain

\section{Introduction}

Angiogenesis, which is regulated by a fine balance between pro- and antiangiogenic signals, represents a key event in the development of tumors. In the absence of oxygen in the tumor nucleus, expression of some transcriptional factors, such as hypoxia inducible factor (HIF), is induced. HIF enhances the expression of pro-angiogenic factors such as vascular endothelial growth factor (VEGF) and plateletderived growth factor (PDGF). VEGF is an important inducer of angiogenesis, the expression of which is also controlled by different oncoproteins such as epidermal growth factor (EGF), K-ras, and PDGF, among others $[1,2]$.

Immune dysfunction has been well documented in cancer patients, including those affected by renal cell carcinoma (RCC) [3-5]. RCC patients present a shift from a type-1-mediated $\mathrm{CD} 4^{+} \mathrm{T}$ cell response producing interferon gamma (IFN $\gamma$ ) to a type-2 cytokine response, involving interleukins (IL) 4, 5, and 10. Type-1-mediated $\mathrm{CD}^{+} \mathrm{T}$ cell response is critical for the development of effective antitumor immunity, while type- 2 cytokine response typically mediates humoral immunity. More specifically, tumor-specific $\mathrm{T}$ cell response to tumor-associated antigens MAGE- 6 and EphA2 is characterized by a predominance of T cells synthesizing IL5 and IL4, together with reduced levels or a complete absence of $\mathrm{T}$ lymphocytes expressing IFN $\gamma[6,7]$. However, the diminished type-1 response in RCC patients is not limited to MAGE-6 and EphA2-specific $\mathrm{CD} 4^{+} \mathrm{T}$ cells. It has also been reported that after undergoing primary tumor excision and/or immunotherapy and presenting a disease-free period, IFN $\gamma$-producing type- $1 \mathrm{CD}^{+} \mathrm{T}$ cells prevail in $\mathrm{RCC}$ patients, suggesting that tumor environment may promote a type-2 response [6]. In advanced stages of RCC, the 
peripheral blood lymphocyte response also changes from predominantly type 1 to type 2 after polyclonal activation [8].

Antiangiogenic molecules can inhibit many immunosuppressive mechanisms, such as regulatory $\mathrm{T}$ (Treg) cells, myeloid-derived suppressor cells (MDSCs), immunosuppressive cytokines, and others. Besides, they play a crucial role in inducing an efficient immunostimulatory antitumor response. In this respect, emerging evidence indicates that tyrosine kinase inhibitors (TKIs) modulate hematopoiesis and immune functions [9], and their effect on myelopoiesis depends on their different selectivity for c-kit and FLT3 receptors, expressed on hematopoietic stem cells and precursor cells $[9,10]$.

\section{Proangiogenic factors}

When proangiogenic factors are induced by hypoxia or oncoproteins, the balance between pro- and antiangiogenic factors is deregulated, resulting in proliferation and migration of vascular cells and the formation of new blood vessels. The structure of new blood vessels is altered, resulting in distorted and enlarged vessels, increased permeability, irregular blood flow, and microhemorrhages in the tumor. This deregulation also leads to reduced lymphocyte infiltration in the tumor [11]. Some of these proangiogenic molecules, such as VEGF, placental growth factor (PIGF), and hepatocyte growth factor (HGF) are able to modulate immunity $[12,13]$.

VEGF-A is also involved in the induction of tumor immunosuppression at different levels. First, tumor-derived VEGF-A can inhibit transcription nuclear factor- $\kappa \mathrm{B}$ (NF$\kappa B)$ via VEGFR-1 signaling and thereby prevent dendritic cell (DC) maturation $[13,14]$. In cancer patients, increases in VEGF plasma levels are also correlated with the presence of immature DCs and immature myeloid cells in peripheral blood [15]. In tumor-bearing mice and metastatic colorectal cancer patients, VEGF-A can directly activate Treg cell proliferation in a VEGFR-2-dependent manner [16], as well as contributing to tumor-associated macrophage (TAM) development, by inducing the recruitment of monocytes/macrophages to the tumor. It has also been reported that VEGF-A administration decreases the proportion and number of splenic $\mathrm{T}$ cells and suppresses their function [17].

PIGF prevents DC differentiation [13] and inhibits the capacity of human myeloid-derived DCs to stimulate a Th1 response, as demonstrated in some in vitro experiments [18]. HGF, produced by a large number of tumors, such as carcinomas, soft tissue sarcoma, and hematopoietic malignancies, is implicated in tumor angiogenesis [19], while its receptor c-met is not only expressed by diverse tumor cells, but also present on the surface of immune cells such as DCs [20].

\section{Immunosuppressive cells}

\section{Myeloid-derived suppressor cells}

MDSCs are immature myeloid cells that, in chronic inflammatory conditions, fail to eventually differentiate into granulocytes, macrophages or DCs [21, 22]. MDSCs comprise a very heterogeneous population that can present widely distinct phenotypical characteristics [23-25], although they always exhibit remarkable immunosuppressive and tumorigenic activities [23-26].

Two subsets of human MDSCs can be distinguished: granulocytic MDSCs (Lin-HLA-DR-CD33 ${ }^{+}$or $\mathrm{CD} 1 \mathrm{~b}^{+}$ CD14-CD $\left.15^{+}\right)$and monocytic MDSCs $\left(14^{+}\right.$HLA-DR ${ }^{\text {neg/lo }}$ or $\mathrm{CD}_{11 b^{+}} \mathrm{CD}_{14}{ }^{+} \mathrm{HLD}-\mathrm{DR} \mathrm{R}^{\text {neg/o }}$ ) [24-27].

MDSC tumorigenic activity includes the secretion of angiogenic factors promoting neoangiogenesis [28], the production of growth factors, matrix metalloproteinases and cytokines that activate Th2 type and Treg cells [29-31] and the deprivation of arginine and cysteine necessary for $\mathrm{T}$ cell functions [25, 32]. MDSCs also enhance the production of nitric oxide and reactive oxygen species, causing $\mathrm{T}$ cell receptor (TCR) nitration or T cell apoptosis [25], the expression of membrane-bound transforming growth factor beta 1 (TGF- $\beta 1$ ), inducing anergy of immune effector cells $[25,33]$ and a down-regulation of the TCR-chain expression, disabling the capacity of $\mathrm{T}$ cells to transmit activation signals [25].

In summary, MDSCs create favorable conditions for tumorigenesis, tumor growth, metastasis, and neoangiogenesis, and confer tumor resistance to antiangiogenic drugs [34]. These processes are tightly interrelated and are governed by MDSC-derived mediators, such as apoptotic factors (TNF- $\alpha$ ), interleukins (IL-1, IL-6), growth factors [TGF- $\beta$, VEGF, basic fibroblast growth factor (bFGF)], and HIF- $1 \alpha$. The presence of MDSCs has been described in RCC patients and can account for their impaired immune response [35].

Therefore, understanding the mechanism and checkpoint regulators of MDSC-tumor interaction is critically important to overcome immunosuppression and to achieve better therapeutic effects in cancer patients.

\section{Dendritic cells}

DCs are efficient antigen-presenting cells that can present tumor-specific antigens and subsequently activate a specific antitumor $\mathrm{T}$ cell response in vivo. Immature DCs process antigens and then mature to activated DCs, 
subsequently eliciting a productive immune response. DCs are not often found in tumor infiltrates [36], although sometimes they can be found in an immature state, unable to induce an effective immune response [37].

DCs have been shown to induce immune tolerance in several ways, including $\mathrm{T}$ cell deletion [38, 39], induction of $\mathrm{T}$ cell unresponsiveness [40] and Treg activation [41-43]. Immature DCs have been shown to silence immunity and to induce immune tolerance by inhibiting $\mathrm{T}$ cells or activating Treg cells [41] through tumor-derived factors, such as VEGF, IL-6, and macrophage colonystimulating factor [44, 45].

Once activated, antigen-loaded DCs activate antigenspecific immunity [46], through $\mathrm{T}$ cell proliferation and differentiation into helper and effector cells. DCs also play an important role in humoral immunity, as they directly interact with B cells [47] and present unprocessed antigens [48].

Numerous studies in humans have concluded that DCs can infiltrate and fight tumors, through at least two pathways: directly via DC-dependent tumor cytokines and indirectly, via the induction of potent cytotoxic T-lymphocyte (CTL) responses.

In the context of RCC, it is important to highlight that carcinogenic cells have been described as inhibiting DC maturation, DC-induced $\mathrm{T}$ cell activation, and antitumor CTL response, by releasing IL-6 and VEGF [49]. Besides, increased tumor infiltration of DCs has been shown as a predictor for treatment response and an outcome in mRCC patients treated with immunotherapy [50].

\section{$\mathrm{T}$ regulatory cells}

There is growing evidence that $\mathrm{CD} 4^{+} \mathrm{CD} 5^{+}$Treg cells may play an important role in suppressing the development of antitumor immunity in cancer patients [51] and that the number of Treg cells is increased in tumor sites and/or the peripheral blood of patients with advanced tumors [52-54].

\section{Natural killer cells}

Natural killer (NK) cells are part of the hematopoietic system and are derived from $\mathrm{CD} 34^{+}$hematopoietic progenitor cells [55-57]. NK cells recognize and lyse tumor cells with no need for maturation or major histocompatibility complex recognition; besides, they are thought to be involved in immune surveillance against cancer [58, 59]. There is also some evidence of the critical role of NK cells in angiogenesis inhibition by IL-12-induced IFN $\gamma$ secretion. In RCC terms, the presence of lymphocytic infiltrate with high levels of NK cells has been described as a good prognostic factor [60].

\section{Monocytes/macrophages}

Monocytes/macrophages represent a quantitative and functionally important subpopulation within the tumor microenvironment. TAMs are derived from circulating peripheral blood monocytes attracted to the tumor site by chemotactic factors, such as colony stimulating factor 1 , which also induce macrophage differentiation [61] and are involved in malignant progression. TAMs mediate their immunosuppressive activity by releasing inhibitory cytokines such as TGF- $\beta$ and enhancing the production of IL-10 [62].

In addition, TAMs produce large amounts of VEGF and might be responsible for the tumor angiogenic switch [63]. In RCC, the number of TAMs significantly correlates with tumor microvessel density and VEGF levels [64].

\section{Immune dysfunction: type 1/type 2 bias}

In RCC patients, there is a shift from a type-1-mediated $\mathrm{CD}^{+}{ }^{+} \mathrm{T}$ cell response producing IFN $\gamma$, which is critical for the development of effective antitumor immunity, to a type- 2 cytokine IL-4, IL-5, and IL-10 response that typically mediates humoral immunity [65].

Type- 2 bias exists in $\mathrm{T}$ cells from $\mathrm{mRCC}$ patients, as tumor-specific $\mathrm{CD}^{+}{ }^{+} \mathrm{T}$ cells displaying a T-helper type-2 bias have been isolated from $\mathrm{mRCC}$ patients [6, 7]. Additional studies have shown that a type-2 bias is present in $\mathrm{T}$ cells from $\mathrm{mRCC}$ patients after polyclonal stimulation of peripheral blood mononuclear cells (PBMC) with antiCD3/anti-CD28 antibodies [8, 66, 67]. When compared with healthy donors, mRCC patients show a significant reduction in the percentage of $\mathrm{CD} 4^{+} \mathrm{T}$ cells expressing intracellular IFN $\gamma$, whereas the percentage of IL-4 ${ }^{+} \mathrm{T}$ cells was similar in both. Moreover, it has been demonstrated that RCC patients whose tumor environment is biased toward a type- 1 immune response have a more favorable prognosis [68].

\section{Modulation of immune cells by tyrosine kinase inhibitors}

Two kinds of antiangiogenic molecules are currently available: TKIs, which target receptors of proangiogenic factors and block their signaling functions; and monoclonal antibodies, which directly target circulating proangiogenic factors or their receptors.

Immune therapy usually requires time to generate, activate, and stimulate an antitumor immune response. Previous reports have described how antiangiogenic treatment could normalize tumor vessels as early as 2 days 
post-treatment $[69,70]$. Therefore, the combined treatment schedule should be designed to synchronize vascular normalization and $\mathrm{T}$ cell activation. A previous study has suggested that antiangiogenic therapy preceding vaccine therapy has a better antitumor effect than vaccine therapy followed by antiangiogenic treatment [71]. Recently, immunotherapy with nivolumab showed longer overall survival than everolimus among patients with advanced RCC previously treated with antiangiogenic therapies [72]. A subgroup analysis of this last study found that patients previously treated with pazopanib showed a statistically significant increase in overall survival with nivolumab, while patients previously treated with sunitinib showed insignificant differences in overall survival between nivolumab and everolimus. This suggests that different TKIs might enhance subsequent immunotherapy by different mechanisms [73]. Thus, studies comparing the efficacy of different combination schedules might yield even better treatment regimens in the future.

The TKIs, sunitinib, pazopanib, sorafenib, and axitinib, have an impact not only on both tumor growth and angiogenesis, but also on the activity and function of immune effector cells. TKI treatment results in a dramatic reduction of $\mathrm{T}$ cell proliferation, along with distinct repercussions on cell cycle progression. Administration of TKIs reduces absolute neutrophil [74], monocyte [75], and lymphocyte counts [76, 77]. Of these, monocyte count undergoes the largest proportional decrease [78]. Patients with clinical benefit have a significantly smaller decrease in monocyte levels during the first cycle of treatment than patients with progressive disease [78]. A decrease in the absolute neutrophil count was associated with longer time to progression [79], while a decrease in total number of lymphocytes after sunitinib treatment has shown no benefit in terms of overall survival, when compared to patients with stable or increased total lymphocytes count [76]. Platelets also seem to play a role in the inmune response. Cysteine-rich protein 61(CYR61) connective tissue growth factor nephroblastoma overexpressed 1 (CCN1) is produced by endothelium cells and platelets and coats the internal side of the blood vessel. The increase of CCN1 amount is essential both for the recruitment of resident monocytes and for their patrolling activity. Without platelets in the blood, the CCN1 level will not rise and, therefore, the early arrival of Ly6 $\mathrm{C}^{\text {low }}$ monocytes will be impaired and the recruitment of neutrophils abolished. Treatments that decrease the number of platelets may compromise the start of immune response [80]. This reduction in immune cells counts might explain, at least in part, some of the hematologic side effects of TKIs.

Targeting immunosuppressive cells might improve antitumor $\mathrm{T}$ cell response, thereby providing a rationale for the combination of TKIs with immunotherapy in the treatment of RCC.

Some studies suggest that Treg cells may be involved in modulating type- 1 and type- 2 cytokine response and that a reduction in their level is associated with an increase in $\mathrm{T}$ cell function as measured via IFN- $\gamma$ levels [77]. Likewise, this increase in $\mathrm{T}$ cell function is also correlated with a reduction in MDSC populations, suggesting that both MDSCs and Treg cells are contributing to immune dysfunction in mRCC patients.

TKIs induce a reduction in Treg cell levels in mRCC patients. Their effect on Treg cell levels in peripheral blood has been examined in patients before sunitinib treatment and on day 28 of both first and second cycles. Compared to pretreatment values, the percentage of Treg cells was reduced after 1 cycle, although the reduction did not reach statistical significance. However, a negative correlation between the decreases of Treg cells after 1 or 2 cycles of treatment, and the increase of IFN $\gamma$-producing $\mathrm{CD}^{+} \mathrm{T}$ cells, was shown at the end of cycle 2 . A negative correlation was also seen with the IFN $\gamma$ response of total $\mathrm{T}$ cells $\left(\mathrm{CD}^{+}\right)$population [77]. Thus, these findings may support the fact that the greater the reduction of Treg cells following 1 or 2 cycles of treatment, the stronger the type- 1 response after 2 cycles of treatment [77].

The results reviewed here suggest that TKIs may have an effect on Treg cell population resulting in improved type-1 cytokine response. One plausible explanation for these findings is that the restoration of a type- 1 IFN $\gamma$ response is related to a decrease in the immunosuppressive tumor burden.

The hypothesis that the clinical response induced by TKIs is influenced by the degree of type- 2 bias at baseline could be explained either by an immune mechanism of this therapeutic family or by the importance of parallel mechanisms of antitumor effect (TKI-induced antiangiogenic and innate immune response).

TKIs can reverse the immune suppression caused by Treg or MDSCs [77, 81, 82] and improve type $1 \mathrm{~T}$ cell cytokine response [77, 82-84], and these immunologic effects are currently under discussion. Moreover, the expression of negative co-stimulatory molecules, such as CTLA4 and PD-1 in CD4 ${ }^{+}$and $\mathrm{CD}^{+}{ }^{+} \mathrm{T}$ cells, has also been shown to significantly decrease in sunitinib-treated mice [82], whereas a decrease of the $\mathrm{T}$ cell-mediated immune response has been observed upon sunitinib treatment in another murine model [85].

Some mechanisms that might explain the reduction of TKI-induced Treg cells, such as MDSC inhibition [81] or blockage of the conversion of conventional CD4 ${ }^{+}$Foxp $^{-}$ $\mathrm{T}$ cells into $\mathrm{CD}^{+}{ }^{+}$Foxp3 ${ }^{+}$Treg cells [86], have been described. 
TKIs seem to modulate MDSCs in different ways, such as: (1) inhibition of signal transducer and activator of transcription 3 (STAT3) [87], (2) induction of monocytic subset $\left(\mathrm{Gr}^{10}\right)$ of MDSC proliferation, and (3) apoptosis of the granulocytic subset $\left(\mathrm{Gr}^{\mathrm{hi}}{ }^{\text {) }}\right.$ of MDSCs [34]. In mRCC patients, the proportion of all MDSC subsets (immature lin $^{-}$, monocytic $\mathrm{CD} 33^{+} \mathrm{CD}^{+} 4^{+} \mathrm{DR}^{-}$and granulocytic $\mathrm{CD}_{3}{ }^{+} \mathrm{CD} 15^{+} \mathrm{DR}^{-}$) has been shown to decrease in peripheral blood after the first cycle of sunitinib treatment [81]. Similarly, only patients who do not respond to pazopanib treatment show increased MDSCs [84]. More importantly, MDSCs, either directly or through the induction of Treg cells, are involved in the development of TKI resistance [88].

TKIs could also regulate the expression of NK cell ligands, activating receptors in tumor cells. Thus, sunitinib and sorafenib induce NKG2D ligand expression, which confers enhanced sensitivity to NK cell lysis [89, 90]. Sorafenib also inhibits spontaneous and IL-2-induced NK effector functions [91], while axitinib has been shown to strongly suppress $\mathrm{T}$ cells proliferation, which might possibly affect the expansion of tumor-specific $\mathrm{T}$ cells [92]. In addition, axitinib enhances NK cell recognition and activity against RCC cells, by regulating NK cell-activating ligand expression [93].

Sorafenib inhibits DC antigen presentation and can stimulate primary $\mathrm{T}$ cell responses, by reducing the secretion of cytokines or the expression of MHC and CD1a molecules [94]. More importantly, its action in reversing the inhibitory effects of VEGF on monocyte-derived DC maturation and DC-mediated $\mathrm{T}$ cell stimulation has also been demonstrated [95]. The immunomodulatory effects of sorafenib on monocytes and macrophages have also been reported to induce autophagy and suppression of human macrophages [96].

Low doses of antiangiogenic treatment (sorafenib and sunitinib) have been shown to normalize tumor vasculature and polarize TAMs, thus reducing immune-regulatory signals and thereby creating an immune-supportive microenvironment for the recruitment and activatation of CD8+ T cells [89]. By this mechanism, low-dose antiangiogenic treatment enhances the anticancer efficacy of a vaccine therapy. In contrast, high-dose antiangiogenic treatment excessively reduces tumor vessels, thus decreasing the delivery of chemotherapeutics [97, 98]. High-dose antiangiogenic treatment may also exacerbate, rather than reverse, the immunosuppressive tumor microenvironment, thus compromising the efficacy of active cancer immunotherapy. Therefore, these studies suggest that appropriate low-dose antiangiogenic treatment could be an effective strategy to reengineer the tumor microenvironment for active immunotherapies in a clinical setting.

\section{Conclusions and future perspective}

The existence of several tumor-mediated immunosuppressive networks operating in RCC that impede the success of immune-based therapies is now widely accepted. One of them involves tumor-induced accumulation of MDSCs [99].

Emerging data indicate that abnormal tumor vasculature, resulting from the prevalence of proangiogenic factors over antiangiogenic signals, fosters an immunosuppressive tumor microenvironment, which in turns enables host immunosurveillance evasion by the tumor. Proangiogenic factors not only suppress the function of various immune cells but also diminish leukocyte-endothelial interactions and hinder the infiltration of immune effector cells into the tumor parenchyma.

The induction of high levels of tumor-specific cytotoxic $\mathrm{T}$ lymphocytes is a prerequisite for successful cancer immunotherapy. Unfortunately, the presence of a high number of tumor antigen-specific cytotoxic $\mathrm{T}$ cells in peripheral immune organs is associated with little clinical benefit, so other factors, such as tumor microenvironment, considered a key player, must be involved in this poor clinical outcome.

Immunotherapy of mRCC has evolved from a rather unspecific (e.g. cytokine era) to a more specific (e.g. checkpoint inhibitors) approach. Immunological checkpoints can either inhibit or activate $\mathrm{T}$ cells, leading to speculation as to whether immunomodulation should target $\mathrm{T}$ cell-inhibiting or $\mathrm{T}$ cell-activating co-stimulatory molecules. The fact that TKIs can improve type- $1 \mathrm{~T}$ cell cytokine response while reducing both number and function of Treg cells, provides a basis for the rational combination of TKIs and immunotherapy in mRCC.

This mechanism is currently under investigation, although it is likely to be in part due to MDSC reduction which inhibits $\mathrm{T}$ cell function directly.

Administration of TKIs before vaccination induces higher antitumor efficacy than post-vaccination or simultaneous administration. The modulation of tumor-induced immunosuppression, which results in a better induction of antigen-specific $\mathrm{CD}^{+} \mathrm{T}$ cells after vaccination, could explain this synergy. TKIs could normalize tumor vascularization transiently, thus helping $\mathrm{CD}^{+} \mathrm{T}$ cell influx into the tumor after vaccination. Vascular normalization could also be accompanied by decreased hypoxia. Since hypoxia seems to be involved in the development of immunosuppressive mechanisms, its suppression could represent a mechanism for modulating tumor-induced immunosuppression.

CheckMate-025 sub-analyses revealed potential outcome differences with nivolumab following pazopanib and 
sunitinib, showing only statistically significant increase in the overall survival only in the case of pazopanib. Taking this into account, analyzing tumor samples from the PISCES trial would be of great interest to study whether pazopanib is a better primer compared to sunitinib, before a second line immunomodulator.

To summarize, rationally scheduled antiangiogenic treatment can transiently normalize tumor vessels, improve vessel perfusion, decrease hypoxia and enhance the efficacy of cytotoxic therapies.

Acknowledgements The development of this work has been possible thanks to the financial support of Novartis Oncology. Authors would like to thank the support of GOC Networking team, especially to Jemina Moreto, for their collaboration and work during the development manuscript.

\section{Compliance with ethical standards}

Conflicts of interest The authors declare that they have no conflict of interest.

Ethical approval This article does not contain any studies with human participants performed by any of the authors.

Open Access This article is distributed under the terms of the Creative Commons Attribution 4.0 International License (http://crea tivecommons.org/licenses/by/4.0/), which permits unrestricted use, distribution, and reproduction in any medium, provided you give appropriate credit to the original author(s) and the source, provide a link to the Creative Commons license, and indicate if changes were made.

\section{References}

1. Perrotte P, Matsumoto T, Inoue K, Kuniyasu H, Eve BY, Hicklin DJ, et al. Antiepidermal growth factor receptor antibody $\mathrm{C} 225$ inhibits angiogenesis in human transitional cell carcinoma growing orthotopically in nude mice. Clin Cancer Res. 1999;5(2):257-65.

2. Rak J, Yu JL, Klement G, Kerbel RS. Oncogenes and angiogenesis: signaling three-dimensional tumor growth. J Investig Dermatol Symp Proc. 2000;5(1):24-33

3. Finke J, Ferrone S, Frey A, Mufson A, Ochoa A. Where have all the T cells gone? Mechanisms of immune evasion by tumors. Immunol Today. 1999;20(4): 158-60.

4. Kiertscher SM, Luo J, Dubinett SM, Roth MD. Tumors promote altered maturation and early apoptosis of monocyte-derived dendritic cells. J Immunol. 2000;164(3):1269-76.

5. Uzzo RG, Rayman P, Kolenko V, Clark PE, Bloom T, Ward AM, et al. Mechanisms of apoptosis in $\mathrm{T}$ cells from patients with renal cell carcinoma. Clin Cancer Res. 1999;5(5):1219-29.

6. Tatsumi T, Herrem CJ, Olson WC, Finke JH, Bukowski RM, Kinch MS, et al. Disease stage variation in CD4+ and CD8 + T-cell reactivity to the receptor tyrosine kinase EphA2 in patients with renal cell carcinoma. Cancer Res. 2003;63(15):4481-9.

7. Tatsumi T, Kierstead LS, Ranieri E, Gesualdo L, Schena FP, Finke JH, et al. Disease-associated bias in T helper type $1(\mathrm{Th} 1) / \mathrm{Th} 2 \mathrm{CD} 4(+) \mathrm{T}$ cell responses against MAGE-6 in HLA-DRB10401(+) patients with renal cell carcinoma or melanoma. J Exp Med. 2002;196(5):619-28

8. Onishi T, Ohishi Y, Imagawa K, Ohmoto Y, Murata K. An assessment of the immunological environment based on intratumoral cytokine production in renal cell carcinoma. BJU Int. 1999;83(4):488-92.

9. Santoni M, Rizzo M, Burattini L, Farfariello V, Berardi R, Santoni G, et al Present and future of tyrosine kinase inhibitors in renal cell carcinoma: analysis of hematologic toxicity. Recent Pat Antiinfect Drug Discov. 2012;7(2):104-10.

10. Kumar R, Crouthamel MC, Rominger DH, Gontarek RR, Tummino PJ, Levin RA, et al. Myelosuppression and kinase selectivity of multikinase angiogenesis inhibitors. Br J Cancer. 2009;101(10):1717-23.
11. oude Tromp SC, Egbrink MG, Dings RP, van Velzen S, Slaaf DW, Hillen HF, et al. Tumor angiogenesis factors reduce leukocyte adhesion in vivo. Int Immunol. 2000;12(5):671-6.

12. Benkhoucha M, Santiago-Raber ML, Schneiter G, Chofflon M, Funakoshi H, Nakamura T, et al. Hepatocyte growth factor inhibits CNS autoimmunity by inducing tolerogenic dendritic cells and CD25+ Foxp3+ regulatory $\mathrm{T}$ cells. Proc Natl Acad Sci USA. 2010;107(14):6424-9.

13. Dikov MM, Ohm JE, Ray N, Tchekneva EE, Burlison J, Moghanaki D, et al. Differential roles of vascular endothelial growth factor receptors 1 and 2 in dendritic cell differentiation. J Immunol. 2005;174(1):215-22.

14. Oyama T, Ran S, Ishida T, Nadaf S, Kerr L, Carbone DP, et al. Vascular endothelial growth factor affects dendritic cell maturation through the inhibition of nuclear factor-kappa B activation in hemopoietic progenitor cells. J Immunol. 1998;160(3):1224-32.

15. Osada T, Chong G, Tansik R, Hong T, Spector N, Kumar R, et al. The effect of anti-VEGF therapy on immature myeloid cell and dendritic cells in cancer patients. Cancer Immunol Immunother. 2008;57(8):1115-24.

16. Wagner KD, Ambrosini P, Rynn M, Wohlberg C, Yang R, Greenbaum MS, et al. Efficacy of sertraline in the treatment of children and adolescents with major depressive disorder: two randomized controlled trials. JAMA. 2003;290(8):1033-41.

17. Gabrilovich D, Ishida T, Oyama T, Ran S, Kravtsov V, Nadaf S, et al. Vascular endothelial growth factor inhibits the development of dendritic cells and dramatically affects the differentiation of multiple hematopoietic lineages in vivo. Blood. 1998;92(11):4150-66.

18. Lin YL, Liang YC, Chiang BL. Placental growth factor down-regulates type $1 \mathrm{~T}$ helper immune response by modulating the function of dendritic cells. J Leukoc Biol. 2007;82(6): 1473-80.

19. Bussolino F, Di Renzo MF, Ziche M, Bocchietto E, Olivero M, Naldini L, et al Hepatocyte growth factor is a potent angiogenic factor which stimulates endothelial cell motility and growth. J Cell Biol. 1992;119(3):629-41.

20. Kurz SM, Diebold SS, Hieronymus T, Gust TC, Bartunek P, Sachs M, et al. The impact of c-met/scatter factor receptor on dendritic cell migration. Eur $\mathrm{J}$ Immunol. 2002;32(7):1832-8.

21. Wilcox RA. Myeloid-derived suppressor cells: therapeutic modulation in cancer. Front Biosci. 2012;4:838-55.

22. Wu L, Yan C, Czader M, Foreman O, Blum JS, Kapur R, et al. Inhibition of $\operatorname{PPAR} \gamma$ in myeloid-lineage cells induces systemic inflammation, immunosuppression, and tumorigenesis. Blood. 2012;119(1):115-26.

23. Chioda M, Peranzoni E, Desantis G, Papalini F, Falisi E, Solito S, et al. Myeloid cell diversification and complexity: an old concept with new turns in oncology. Cancer Metast Revi. 2011;30(1):27-43.

24. Filipazzi P, Huber V, Rivoltini L. Phenotype, function and clinical implications of myeloid-derived suppressor cells in cancer patients. Cancer Immunol Immunother. 2012;61(2):255-63.

25. Ostrand-Rosenberg S, Sinha P. Myeloid-derived suppressor cells: linking inflammation and cancer. J Immunol. 2009;182(8):4499-506.

26. Youn JI, Gabrilovich DI. The biology of myeloid-derived suppressor cells: the blessing and the curse of morphological and functional heterogeneity. Eur $\mathrm{J}$ Immunol. 2010;40(11):2969-75.

27. Peranzoni E, Zilio S, Marigo I, Dolcetti L, Zanovello P, Mandruzzato S, et al. Myeloid-derived suppressor cell heterogeneity and subset definition. Curr Opin Immunol. 2010;22(2):238-44.

28. Tartour E, Pere H, Maillere B, Terme M, Merillon N, Taieb J, et al. Angiogenesis and immunity: a bidirectional link potentially relevant for the monitoring of antiangiogenic therapy and the development of novel therapeutic combination with immunotherapy. Cancer Metas Rev. 2011;30(1):83-95.

29. Gabrilovich DI, Nagaraj S. Myeloid-derived suppressor cells as regulators of the immune system. Nat Rev Immunol. 2009;9(3):162-74.

30. Qu P, Yan C, Du H. Matrix metalloproteinase 12 overexpression in myeloid lineage cells plays a key role in modulating myelopoiesis, immune suppression, and lung tumorigenesis. Blood. 2011;117(17):4476-89.

31. Serafini P, Mgebroff S, Noonan K, Borrello I. Myeloid-derived suppressor cells promote cross-tolerance in B-cell lymphoma by expanding regulatory $\mathrm{T}$ cells. Cancer Res. 2008;68(13):5439-49.

32. Ostrand-Rosenberg S. Myeloid-derived suppressor cells: more mechanisms for inhibiting antitumor immunity. Cancer Immunol Immunother. 2010;59(10): 1593-600.

33. Li H, Han Y, Guo Q, Zhang M, Cao X. Cancer-expanded myeloid-derived suppressor cells induce anergy of NK cells through membrane-bound TGF-beta 1. J Immunol. 2009;182(1):240-9.

34. Ko JS, Rayman P, Ireland J, Swaidani S, Li G, Bunting KD, et al. Direct and differential suppression of myeloid-derived suppressor cell subsets by sunitinib is compartmentally constrained. Cancer Res. 2010;70(9):3526-36.

35. Sakaguchi S, Sakaguchi N, Shimizu J, Yamazaki S, Sakihama T, Itoh M, et al. Immunologic tolerance maintained by $\mathrm{CD} 25+\mathrm{CD} 4+$ regulatory $\mathrm{T}$ cells: their common role in controlling autoimmunity, tumor immunity, and transplantation tolerance. Immunol Rev. 2001;182:18-32.

36. Kataki A, Scheid P, Piet M, Marie B, Martinet N, Martinet Y, et al. Tumor infiltrating lymphocytes and macrophages have a potential dual role in lung cancer by supporting both host-defense and tumor progression. J Lab Clin Med. $2002 ; 140(5): 320-8$. 
37. Figdor CG, de Vries IJ, Lesterhuis WJ, Melief CJ. Dendritic cell immunotherapy: mapping the way. Nat Med. 2004;10(5):475-80.

38. Volkmann A, Zal T, Stockinger B. Antigen-presenting cells in the thymus that can negatively select MHC class II-restricted $\mathrm{T}$ cells recognizing a circulating self antigen. J Immunol. 1997;158(2):693-706

39. Zal T, Volkmann A, Stockinger B. Mechanisms of tolerance induction in major histocompatibility complex class II-restricted T cells specific for a blood-borne self-antigen. J Exp Med. 1994;180(6):2089-99.

40. Hawiger D, Masilamani RF, Bettelli E, Kuchroo VK, Nussenzweig MC Immunological unresponsiveness characterized by increased expression of CD5 on peripheral $\mathrm{T}$ cells induced by dendritic cells in vivo. Immunity. 2004;20(6):695-705

41. Steinman RM, Nussenzweig MC. Avoiding horror autotoxicus: the importance of dendritic cells in peripheral $\mathrm{T}$ cell tolerance. Proc Natl Acad Sci USA. 2002;99(1):351-8.

42. Wing K, Sakaguchi S. Regulatory $\mathrm{T}$ cells exert checks and balances on self tolerance and autoimmunity. Nat Immunol. 2010;11(1):7-13.

43. Zheng Y, Josefowicz S, Chaudhry A, Peng XP, Forbush K, Rudensky AY. Role of conserved non-coding DNA elements in the Foxp3 gene in regulatory T-cell fate. Nature. 2010;463(7282):808-12.

44. Inoshima N, Nakanishi Y, Minami T, Izumi M, Takayama K, Yoshino I, et al. The influence of dendritic cell infiltration and vascular endothelial growth factor expression on the prognosis of non-small cell lung cancer. Clin Cancer Res. 2002;8(11):3480-6.

45. Menetrier-Caux C, Thomachot MC, Alberti L, Montmain G, Blay JY. IL-4 prevents the blockade of dendritic cell differentiation induced by tumor cells. Cancer Res. 2001;61(7):3096-104.

46. Finkelman FD, Lees A, Birnbaum R, Gause WC, Morris SC. Dendritic cells can present antigen in vivo in a tolerogenic or immunogenic fashion. J Immunol. 1996;157(4):1406-14.

47. Jego G, Pascual V, Palucka AK, Banchereau J. Dendritic cells control B cell growth and differentiation. Curr Dir Autoimmun. 2005;8:124-39.

48. Batista FD, Harwood NE. The who, how and where of antigen presentation to B cells. Nat Rev Immunol. 2009;9(1):15-27.

49. Cabillic F, Bouet-Toussaint F, Toutirais O, Rioux-Leclercq N, Fergelot P, de la Pintière CT, et al. Interleukin-6 and vascular endothelial growth factor release by renal cell carcinoma cells impedes lymphocyte-dendritic cell cross-talk. Clin Exp Immunol. 2006;146(3):518-23.

50. Kobayashi M, Suzuki K, Yashi M, Yuzawa M, Takayashiki N, Morita T. Tumor infiltrating dendritic cells predict treatment response to immmunotherapy in patients with metastatic renal cell carcinoma. Anticancer Res. 2007;27(2): $1137-41$.

51. Curiel TJ. Tregs and rethinking cancer immunotherapy. J Clin Invest. 2007;117(5):1167-74.

52. Curiel TJ, Coukos G, Zou L, Alvarez X, Cheng P, Mottram P, et al. Specific recruitment of regulatory $T$ cells in ovarian carcinoma fosters immune privilege and predicts reduced survival. Nat Med. 2004;10(9):942-9.

53. Ormandy LA, Hillemann T, Wedemeyer H, Manns MP, Greten TF, Korangy F. Increased populations of regulatory $\mathrm{T}$ cells in peripheral blood of patients with hepatocellular carcinoma. Cancer Res. 2005;65(6):2457-64.

54. Wolf AM, Wolf D, Steurer M, Gastl G, Gunsilius E, Grubeck-Loebenstein B. Increase of regulatory $\mathrm{T}$ cells in the peripheral blood of cancer patients. Clin Cancer Res. 2003;9(2):606-12.

55. Galy A, Travis M, Cen D, Chen B, Human T. B, natural killer, and dendritic cells arise from a common bone marrow progenitor cell subset. Immunity. 1995;3(4):459-73.

56. Miller JS, Alley KA, McGlave P. Differentiation of natural killer (NK) cells from human primitive marrow progenitors in a stroma-based long-term culture system: identification of a CD34+ 7 + NK progenitor. Blood. 1994;83(9): 2594-601.

57. Shibuya A, Kojima H, Shibuya K, Nagayoshi K, Nagasawa T, Nakauchi H. Enrichment of interleukin-2-responsive natural killer progenitors in human bone marrow. Blood. 1993;81(7):1819-26.

58. Brigati C, Noonan DM, Albini A, Benelli R. Tumors and inflammatory infiltrates: friends or foes? Clin Exp Metastasis. 2002;19(3):247-58.

59. Imai K, Matsuyama S, Miyake S, Suga K, Nakachi K. Natural cytotoxic activity of peripheral-blood lymphocytes and cancer incidence: an 11-year follow-up study of a general population. Lancet. 2000;356(9244):1795-9.

60. Eckl J, Buchner A, Prinz PU, Riesenberg R, Siegert SI, Kammerer R, et al. Transcript signature predicts tissue NK cell content and defines renal cell carcinoma subgroups independent of TNM staging. J Mol Med. 2012;90(1):55-66.

61. Hemmerlein B, Markus A, Wehner M, Kugler A, Zschunke F, Radzum HJ. Expression of acute and late-stage inflammatory antigens, c-fms, CSF-1, and human monocytic serine esterase 1 , in tumor-associated macrophages of renal cell carcinomas. Cancer Immunol Immunother. 2000;49(9):485-92.

62. Daurkin I, Eruslanov E, Stoffs T, Perrin GQ, Algood C, Gilbert SM, et al Tumor-associated macrophages mediate immunosuppression in the renal cancer microenvironment by activating the 15-lipoxygenase- 2 pathway. Cancer Res. 2011;71(20):6400-9.

63. Wu H, Xu JB, He YL, Peng JJ, Zhang XH, Chen CQ, et al. Tumor-associated macrophages promote angiogenesis and lymphangiogenesis of gastric cancer. J Surg Oncol. 2012;106(4):462-8.
64. Toge H, Inagaki T, Kojimoto Y, Shinka T, Hara I. Angiogenesis in renal cell carcinoma: the role of tumor-associated macrophages. Int $\mathbf{J}$ Urol. 2009;16(10):801-7.

65. Pardoll DM, Topalian SL. The role of CD4+ T cell responses in antitumor immunity. Curr Opin Immunol. 1998;10(5):588-94.

66. Smyth GP, Stapleton PP, Barden CB, Mestre JR, Freeman TA, Duff MD, et al Renal cell carcinoma induces prostaglandin E2 and T-helper type 2 cytokine production in peripheral blood mononuclear cells. Ann Surg Oncol. 2003;10(4):455-62.

67. Zea AH, Rodriguez PC, Atkins MB, Hernandez C, Signoretti S, Zabaleta J, et al Arginase-producing myeloid suppressor cells in renal cell carcinoma patients: a mechanism of tumor evasion. Cancer Res. 2005;65(8):3044-8.

68. Kondo T, Nakazawa H, Ito F, Hashimoto Y, Osaka Y, Futatsuyama K, et al. Favorable prognosis of renal cell carcinoma with increased expression of chemokines associated with a Th1-type immune response. Cancer Sci. 2006;97(8):780-6.

69. Jain RK. Normalization of tumor vasculature: an emerging concept in antiangiogenic therapy. Science. 2005;307(5706):58-62.

70. Winkler F, Kozin SV, Tong RT, Chae SS, Booth MF, Garkavtsev I, et al Kinetics of vascular normalization by VEGFR2 blockade governs brain tumor response to radiation: role of oxygenation, angiopoietin-1, and matrix metalloproteinases. Cancer Cell. 2004;6(6):553-63.

71. Farsaci B, Higgins JP, Hodge JW. Consequence of dose scheduling of sunitinib on host immune response elements and vaccine combination therapy. Int $\mathrm{J}$ Cancer. 2012;130(8): 1948-59.

72. Motzer RJ, Escudier B, McDermott DF, George S, Hammers HJ, Srinivas S, et al. Nivolumab versus everolimus in advanced renal-cell carcinoma. N Engl J Med. 2015;373(19):1803-13.

73. Motzer RJ. CheckMate 025 phase III trial of nivolumab versus everolimus in advanced renal cell carcinoma: Outcomes by key baseline factors and prior therapies. In: Padmanee Sharma DFM, Saby George, Hans J. Hammers, Sandhya Srinivas, Scott S. Tykodi, Jeffrey Alan Sosman, Giuseppe Procopio, Elizabeth R. Plimack, Daniel E. Castellano, Howard Gurney, Frede Donskov, Petri Bono, John Wagstaff, Thomas Christoph Gauler, Takeshi Ueda, Huanyu Zhao, Ian M Waxman, Bernard Escudier, Memorial Sloan Kettering Cancer Center NY, NY, The University of Texas MD Anderson Cancer Center H, TX, Beth Israel Deaconess Medical Center B, MA, Roswell Park Cancer Institute B, NY, The Sidney Kimmel Comprehensive Cancer Center at Johns Hopkins B, MD, et al., editors. Motzer RJ, Sharma P, McDermott DF, et al.: CheckMate 025 phase III trial: Outcomes by key baseline factors and prior therapy for nivolumab (NIVO) versus everolimus (EVE) in advanced renal cell carcinoma (RCC). J Clin Oncol. 2016; 34 (suppl 2S; abstr 498). ed. 2016 Genitourinary Cancers Symposium: ASCO University; 2016.

74. Faivre S, Delbaldo C, Vera K, Robert C, Lozahic S, Lassau N, et al. Safety, pharmacokinetic, and antitumor activity of SU11248, a novel oral multitarget tyrosine kinase inhibitor, in patients with cancer. $J$ Clin Oncol. 2006;24(1):25-35.

75. van Cruijsen H, van der Veldt AA, Vroling L, Oosterhoff D, Broxterman HJ, Scheper RJ, et al. Sunitinib-induced myeloid lineage redistribution in renal cell cancer patients: $\mathrm{CD} 1 \mathrm{c}+$ dendritic cell frequency predicts progression-free survival. Clin Cancer Res. 2008;14(18):5884-92.

76. Adotevi O, Pere H, Ravel P, Haicheur N, Badoual C, Merillon N, et al. A decrease of regulatory $\mathrm{T}$ cells correlates with overall survival after sunitinibbased antiangiogenic therapy in metastatic renal cancer patients. J Immunother. 2010;33(9):991-8.

77. Finke JH, Rini B, Ireland J, Rayman P, Richmond A, Golshayan A, et al Sunitinib reverses type- 1 immune suppression and decreases T-regulatory cells in renal cell carcinoma patients. Clin Cancer Res. 2008;14(20):6674-82.

78. Norden-Zfoni A, Desai J, Manola J, Beaudry P, Force J, Maki R, et al. Bloodbased biomarkers of SU11248 activity and clinical outcome in patients with metastatic imatinib-resistant gastrointestinal stromal tumor. Clin Cancer Res. 2007;13(9):2643-50.

79. Walter G, Wiltshire C, Anderson J, Storm V. The pharmacologic treatment of the early phase of first-episode psychosis in youths. Can J Psychiatr. 2001;46(9):803-9.

80. Imhof BA, Jemelin S, Ballet R, Vesin C, Schapira M, Karaca M, et al. CCN1/ CYR61-mediated meticulous patrolling by Ly6Clow monocytes fuels vascular inflammation. Proc Natl Acad Sci USA. 2016;113(33):E4847-56.

81. Ko JS, Zea AH, Rini BI, Ireland JL, Elson P, Cohen P, et al. Sunitinib mediates reversal of myeloid-derived suppressor cell accumulation in renal cell carcinoma patients. Clin Cancer Res. 2009;15(6):2148-57.

82. Ozao-Choy J, Ma G, Kao J, Wang GX, Meseck M, Sung M, et al. The novel role of tyrosine kinase inhibitor in the reversal of immune suppression and modulation of tumor microenvironment for immune-based cancer therapies. Cancer Res. 2009;69(6):2514-22.

83. Edwards JP, Emens LA. The multikinase inhibitor sorafenib reverses the suppression of IL-12 and enhancement of IL-10 by $\mathrm{PGE}_{2}$ in murine macrophages. Int Immunopharmacol. 2010;10(10):1220-8.

84. Pal SK, Hossain DM, Zhang Q, Frankel PH, Jones JO, Carmichael C, et al. Pazopanib as third line therapy for metastatic renal cell carcinoma: clinical efficacy and temporal analysis of cytokine profile. J Urol. 2015;193(4):1114-21. 
85. Gu Y, Zhao W, Meng F, Qu B, Zhu X, Sun Y, et al. Sunitinib impairs the proliferation and function of human peripheral $\mathrm{T}$ cell and prevents $\mathrm{T}$-cell-mediated immune response in mice. Clin Immunol. 2010;135(1):55-62.

86. Kujawski M, Zhang C, Herrmann A, Reckamp K, Scuto A, Jensen M, et al. Targeting STAT3 in adoptively transferred $\mathrm{T}$ cells promotes their in vivo expansion and antitumor effects. Cancer Res. 2010;70(23):9599-610.

87. Xin H, Zhang C, Herrmann A, Du Y, Figlin R, Yu H. Sunitinib inhibition of Stat 3 induces renal cell carcinoma tumor cell apoptosis and reduces immunosuppressive cells. Cancer Res. 2009;69(6):2506-13.

88. Finke J, Ko J, Rini B, Rayman P, Ireland J, Cohen P. MDSC as a mechanism of tumor escape from sunitinib mediated anti-angiogenic therapy. Int Immunopharmacol. 2011;11(7):856-61.

89. Huang Y, Wang Y, Li Y, Guo K, He Y. Role of sorafenib and sunitinib in the induction of expressions of NKG2D ligands in nasopharyngeal carcinoma with high expression of ABCG2. J Cancer Res Clin Oncol. 2011;137(5):829-37.

90. Kohga K, Takehara T, Tatsumi T, Ishida H, Miyagi T, Hosui A, et al. Sorafenib inhibits the shedding of major histocompatibility complex class I-related chain A on hepatocellular carcinoma cells by down-regulating a disintegrin and metalloproteinase 9. Hepatology. 2010;51(4):1264-73.

91. Krusch M, Salih J, Schlicke M, Baessler T, Kampa KM, Mayer F, et al. The kinase inhibitors sunitinib and sorafenib differentially affect NK cell antitumor reactivity in vitro. J Immunol. 2009;183(12):8286-94.

92. Stehle F, Schulz K, Fahldieck C, Kalich J, Lichtenfels R, Riemann D, et al. Reduced immunosuppressive properties of axitinib in comparison with other tyrosine kinase inhibitors. J Biol Chem. 2013;288(23):16334-47.
93. Morelli MB, Amantini C, Santoni M, Soriani A, Nabissi M, Cardinali C, et al Axitinib induces DNA damage response leading to senescence, mitotic catastrophe, and increased NK cell recognition in human renal carcinoma cells. Oncotarget. 2015;6(34):36245-59.

94. Hipp MM, Hilf N, Walter S, Werth D, Brauer KM, Radsak MP, et al. Sorafenib, but not sunitinib, affects function of dendritic cells and induction of primary immune responses. Blood. 2008;111(12):5610-20.

95. Alfaro C, Suarez N, Gonzalez A, Solano S, Erro L, Dubrot J, et al. Influence of bevacizumab, sunitinib and sorafenib as single agents or in combination on the inhibitory effects of VEGF on human dendritic cell differentiation from monocytes. Br J Cancer. 2009;100(7):1111-9.

96. Lin JC, Huang WP, Liu CL, Lee JJ, Liu TP, Ko WC, et al. Sorafenib induces autophagy in human myeloid dendritic cells and prolongs survival of skin allografts. Transplantation. 2013;95(6):791-800.

97. Robert NJ, Diéras V, Glaspy J, Brufsky AM, Bondarenko I, Lipatov ON, et al RIBBON-1: randomized, double-blind, placebo-controlled, phase III trial of chemotherapy with or without bevacizumab for first-line treatment of human epidermal growth factor receptor 2-negative, locally recurrent or metastatic breast cancer. J Clin Oncol. 2011;29(10):1252-60.

98. Van Cutsem E, Lambrechts D, Prenen H, Jain RK, Carmeliet P. Lessons from the adjuvant bevacizumab trial on colon cancer: what next? J Clin Oncol. 2011;29(1):1-4.

99. Ochoa AC, Zea AH, Hernandez C, Rodriguez PC. Arginase, prostaglandins, and myeloid-derived suppressor cells in renal cell carcinoma. Clin Cancer Res. 2007; 13(2 Pt 2):721s-6s. 